Proceedings of the 10th International Ruminant Reproduction Symposium (IRRS 2018); Foz do Iguaçu, PR, Brazil, September 16th to 20th, 2018.

\title{
Seminal plasma proteins and metabolites: effects on sperm function and potential as fertility markers
}

\author{
Arlindo Alencar Moura ${ }^{1, *}$, Erdogan Memili ${ }^{2}$, Antônia Moemia Rodrigues Portela ${ }^{1}$, Arabela Guedes Viana ${ }^{1}$, \\ Ana Luiza Cazaux Velho ${ }^{1}$, Maria Júlia Barbosa Bezerra ${ }^{1}$, Fábio Róger Vasconselos ${ }^{1}$ \\ ${ }^{1}$ Department of Animal Science, Federal University of Ceará, Fortaleza, CE, Brazil. \\ ${ }^{2}$ Department of Dairy and Animal Sciences, Mississippi State University, MS, USA.
}

\begin{abstract}
Molecular components of sperm and in the media surrounding them influence male fertility. In this regard, seminal plasma proteins and metabolites modulate various reproductive events, including sperm motility and capacitation, cell protection, acrosome reaction, fertilization and embryonic development. Empirical associations between seminal proteins and metabolites and fertility indicate that these molecules are potential molecular markers of male reproductive status in cattle and other species.
\end{abstract}

Keywords: fertility, metabolites, proteins, seminal plasma, sperm.

\section{Introduction}

Pregnancy after artificial insemination (AI) is the best indicator of reproductive potential of sires. However, this information usually becomes available only after bulls are mature and have been selected for commercial use in the AI industry. Moreover, criteria such as sperm motility and morphology have limited associations with sire fertility, particularly in bulls selected by the AI industry (Killian et al., 1993; Moura, 2005; Moura et al., 2006; Oliveira et al., 2013; Dogan et al., 2015; Kaya and Memili, 2016). There can be substantial differences in fertility among bulls with normal semen parameters and those with noncompensable sperm defects may never achieve adequate fecundity (Oliveira et al., 2013; Dogan et al., 2015; Kaya and Memili, 2016). Therefore, mechanisms by which sperm molecular profiles influence bull fertility are not fully understood. In this context, there are efforts to identify molecular markers of gamete function in farm animals and humans. Candidate makers include sperm RNA, proteins and various molecules in reproductive fluids. These studies are based on the hypothesis that molecular components of sperm and/or from the surrounding media influence fertilizing capacity. In this regard, analysis of seminal plasma proteome and metabolome will provide information about mechanisms regulating sperm fertilizing potential and reproductive performance. Thus, the present review discusses the roles of selected seminal plasma proteins and metabolites and how their expression relates to fertility, especially in cattle.

\section{Seminal plasma proteins}

\section{Proteins involved in sperm protection}

Seminal plasma contains proteins that protect sperm in the epididymis (Hinton et al., 1995; Kraus et al., 2005), after ejaculation and in the female reproductive tract. Production of reactive oxygen species (ROS) is a component of sperm physiology (MacLeod, 1943); however, excessive ROS disturbs sperm homeostasis through formation of lipid peroxidation, reduction of enzymes that regulate calcium influx, and loss of ATP (Ohta et al., 1989; Aitken et al., 1993). To mitigate deleterious effects of excessive ROS, the epididymis secretes antioxidant enzymes (Hinton et al., 1996), including glutathione Stransferase, tioredoxin peroxidase, superoxide dismutase, glutathione peroxidase (GSHPx) and catalase (Alvarez and Storey, 1983; Jeulin et al., 1989; Fouchécourt et al., 2000; Dacheux et al., 2006). Of these, GSHPx catalyzes the reduction of hydrogen peroxide (Halliwell and Gutteridge, 1990), protecting sperm against excessive ROS (Perry et al., 1992; Dacheux et al., 2005). For example, increased GSPHx activity in ram semen is linked to maintenance of sperm viability (Casao et al., 2010). Another seminal plasma molecule, acidic seminal fluid protein (aSFP), also controls oxidative stress in the bovine reproductive tract (Einspanier et al., 1993; Schöneck et al., 1996). This protein shares identity with molecules of the spermadhesin family (Romão et al., 1997) and, in the bull, is secreted by the epididymis and accessory sex glands (Moura et al., 2007a, 2010). Although aSFP binds to ejaculated sperm, it is lost after capacitation (Dostàlovà et al., 1994). Therefore, unlike porcine spermadhesins (Caballero et al., 2004, 2005), it appears that bovine aSFP does not participate in sperm-oocyte interactions. However, aSFP has been associated with survival of cryopreserved bull sperm (Jobim et al., 2004)

Ion chelators in seminal plasma, such as lactoferrin (LF), also protect sperm against effects of lipid peroxidation (Ochsendorf, 1999). Lactoferrin sequesters ionic iron (Nozaki et al., 2003) and adsorption to sperm during epididymal transit (Jin et al., 1997) and ejaculation (Thaler et al., 1990). In stallions, LF represents $41.2 \%$ of all proteins secreted by the epididymis (Fouchecourt et al., 2000) and high 
concentrations of LF in horse and dog seminal plasma relate to total number of sperm (Kikuchi et al., 2003a, b). Seminal albumin, in turn, binds to lipid peroxides, contributing to sperm protection (Alvarez and Storey, 1983) and is positively correlated with percentage of morphologically normal sperm in bovine semen (Elzanaty et al., 2007).

Clusterin, another seminal plasma molecule with protective roles, acts as a chaperone (Humphreys et al., 1999) and inhibits cell lysis by complementmediated mechanisms present in female secretions (Ibrahim et al., 1999; Meri and Jarva, 2001). In the epididymis, clusterin affects maturation, lipid transport (Tenniswood et al., 1992) and sperm membrane remodeling (Humphreys et al., 1999). Clusterin chaperone activity is consistent with its ability to interact with various types of proteins in vivo (Carver et al.; 2003). In silico analysis of clusterin networking indicates potential interactions with proteases and protease inhibitors, such as plasminogen, alpha-2macroglobulin, TIMP-1, alpha-2-antiplasmin precursor and plasminogen activator inhibitor 1 . Clusterin also has putative links to fibronectins, which participate in cell adhesion, wound healing and maintenance of cell structure, including GTP protein-coupled receptors and modulators of cell growth. Seminal plasma clusterin is inversely related to percentage of sperm with intact membrane in peccaries (Peccari tajacu L.; Santos et al., 2014) and with percentage of morphologically normal sperm in semen from Brahman bulls (BoeHansen et al., 2015). In contrast, bull and ram sperm with morphologic defects have extensive clusterin binding (Ibrahim et al., 2001a, b). This association probably occurs as a result of clusterin's ability to bind to damaged portions of hydrophobic regions of sperm membranes (Bailey and Griswold, 1999). Sertoli cellsecreted clusterin prevented apoptosis in rat testes subjected to hyperthermia (Matsushita et al., 2016) and in humans, clusterin secreted in the fluid of the seminiferous epithelium has positive associations with fertility (Salehi et al., 2013). In addition, seminal clusterin promotes immune tolerance to male antigens in humans, mitigating female immune reactions to male factors (Merlotti et al., 2015). High levels of clusterin are associated with advanced physiopathological states, such as kidney diseases, neurodegenerative disorders, artheriosclerosis, heart attack and cancer (Wehrli et al., 2001; Trougakos et al., 2002; Pucci et al., 2004; Calero et al., 2005). We have characterized the seminal plasma proteome of several domestic and wild species, including bulls (Moura et al., 2007a; Rego et al., 2014, 2016; Menezes et al., 2017), rams (Souza et al., 2012), boars (González-Cadavid et al., 2014), peccaries (Santos et al., 2014), dogs (Aquino-Cortez et al., 2017) and coatis (Silva et al., 2018), among others. Clusterin is present in the semen of all these species, in moderate to high concentrations. Thus, many animals have a clusterin-based, conserved mechanism for sperm protection and regulation of immune reactions initiated by male gametes in the female reproductive tract.

\section{Proteins associated with sperm motility}

Seminal plasma contains various proteins associated with sperm motility (Baas et al., 1983), e.g., kallikrein-cinins. In this case, kininogenin seminal plasma is a specific substrate for kalikrein (Fink et al., 1989), an important stimulator of post-ejaculation sperm motility (Schill et al., 1989). There is a positive correlation between seminal plasma kallikrein activity and sperm motility, with exogenous kallikrein enhancing bovine sperm motility (Somlev et al., 1996). Angiontensin converting enzyme (ACE) is another seminal plasma component related to the kalikrein system (Hohlbruggeret al., 1984). This enzyme catalyzes formation of angiontensin II and binds to receptors on sperm, enhancing motility (Vinson et al., 1996). Furthermore, ACE activity in ram seminal plasma is positively correlated with sperm concentration and fertility (Métayer et al., 2001; Gatti et al., 2004). In contrast, inhibition of ACE activity in bovine seminal plasma decreases progressive motility and inhibits acrosome reaction after in vitro capacitation (Costa and Thundathil, 2012).

Proteins involved in sperm capacitation, acrosome reaction and fertilization

Phospholipid binding proteins belonging to the family of BSPs (Binder of Sperm Proteins) are present in seminal plasma of several species, including bulls, bucks (male goats and rabbits), rams, rodents, stallions and men (Moura et al., 2007a; Manjunath et al., 2009; Souza et al., 2012; Plante et al., 2016). BSPs comprise $\sim 60 \%$ of all proteins of the accessory sex gland fluid (Moura et al., 2007a) and seminal plasma (Manjunath and Sairam, 1987) of Bos taurus bulls and nearly the same amount in seminal plasma of Bos indicus bulls (Rego et al., 2014). In cattle, BSP proteins are secreted as isoforms with 14-15 kDa (BSP1 and BSP3) and 30 $\mathrm{kDa}$ (BSP5). Both BSP1 and BSP5 have two fibronectin type II domains arranged in tandem and amino terminal extensions that are $\mathrm{O}$-glycosylated at threonine residues. Such biochemical attributes allow BSP1 and BSP5 to interact with sperm and to modulate ligand-binding activities by similar mechanisms (Calvete et al., 1996; Manjunath et al., 2009), with functional similarities (Manjunath and Thérien, 2002). Bovine BSPs are typical accessory sex gland proteins (Manjunath and Thérien, 2002; Moura et al., 2007a, 2010). BSPs bind to bull sperm at ejaculation (Manjunath and Thérien, 2002) and remain there after sperm contact oviductal secretions in vitro (Souza et al., 2008), as well as in acrosome-reacted or frozen-thawed sperm (RodriguezVillamil et al., 2016). BSPs also mediate the interaction between sperm and the oviduct epithelium (Gwathmey et al., 2006; Suarez, 2016). The most studied role of BSPs is their ability to bind and remove phospholipids and cholesterol from the sperm membrane, an initial event of capacitation (Thérien et al., 1999). Capacitating 
effects of BSPs have been reported in other species, including mice (Plante and Manjunath, 2015) and humans (Plante et al., 2014). However, while ruminant BSPs originate mainly from the accessory sex glands (Manjunath et al., 2009; Souza et al., 2012; van Tilburg et al., 2014), they are expressed in the epididymis of mice and humans.

In addition to sperm capacitation, BSP1 affects in vitro fertilization and embryonic development. The study conducted by Rodriguez-Villamil et al. (2016) evaluated cumulus-oocyte complexes (COCs) incubated with frozen-thawed ejaculated sperm $(18 \mathrm{~h})$ in FertTALP medium containing: heparin and BSP1. With ejaculated sperm, cleavage rates were similar when Fert-TALP medium was incubated with heparin, 10 or $20 \mu \mathrm{g} / \mathrm{ml}$ BSP1. Day-7 blastocyst rates were equivalent after incubations with heparin or $10 \mu \mathrm{g} / \mathrm{ml} \mathrm{BSP1}$, but there were marked reductions in blastocyst formation after IVF media were supplemented with 20 or 40 $\mu \mathrm{g} / \mathrm{ml}$. Therefore, BSP1 is as efficient as heparin for inducing capacitation and fertilizing capacity of frozenthawed ejaculated sperm. However, damage caused to embryo development may have been caused by BSP1 itself. High concentrations of and/or prolonged exposure to BSP proteins are harmful to cryopreserved sper due to membrane destabilization and excessive phospholipid and cholesterol efflux (Thérien et al., 1995, 1998; Manjunath and Thérien, 2002). Furthermore, content of BSP5 in accessory sex gland fluid has a quadratic association with bull fertility (Moura et al., 2006), suggesting that excessive BSP was detrimental to sperm physiology and/or embryo development.

In the same study (Rodriguez-Villamil et al., 2016), cleavage rates were higher after IVF using cauda epididymal sperm and any BSP1 concentration (10, 20 or $40 \mu \mathrm{g} / \mathrm{ml}$ ) embryo development (day 8) was greater after inclusion of 20 or $40 \mu \mathrm{g} / \mathrm{ml} \mathrm{BSP1}$ in the IVF media, with or without heparin. Thus, we concluded that: 1) heparin has limited effect on cauda epididymal sperm in vitro (based on fertilization rates and blastocyst formation; 2) BSP1 has better effects on embryo growth than heparin; and 3) a combination of BSP1 with heparin does not enhance cleavage rates and embryo development beyond those obtained with BSP1. We also verified that SP1 did not cause reductions in bovine blastocyst growth after IVF with epididymal sperm, in contrast to results obtained with ejaculated sperm. Therefore, previous exposure of sperm or not to seminal plasma determines how sperm will respond to BSP in vitro. Additionally, combining heparin and BSP1 did not increase capacitation rates of ejaculated sperm. And both cleavage rates and blastocyst growth were similar after ejaculated sperm were incubated with heparin, BSP-1+heparin or BSP-1. With epididymal sperm, the best results or capacitation and blastocyst growth were obtained with BSP-1, when compared to heparin and heparin+BSP-1 (Rodriguez-Villamil et al., 2018; Federal University of Ceara, Fortaleza, Brazil; unpublished data). Thus, BSP-1 is a potent capacitating factor for bovine sperm and it increases fertilization rates, with no dependence on heparin.

Despite multiple beneficial roles of BSPs, these molecules can damage sperm during cryostorage, as they extract phospholipids and cholesterol from the membrane in a concentration- and time-dependent manner (Manjunath et al., 2002; Plante et al., 2016). Such deleterious effects occur when sperm are exposed for prolonged periods-and/or to excessive concentrations of BSPs. In this regard, extenders used for sperm preservation, such as egg-yolk (EY) and milk, contain components that associate with BSPs (Manjunath et al., 2002). There are interactions between low-density lipoproteins in EY (Bergeron and Manjunath, 2006) or milk proteins; the latter can prevent excessive BSP binding to sperm and excessive phospholipid removal from the membrane, thereby protecting sperm during cryopreservation (Plante et al., 2015). In goats, milk proteins (casein and $\beta$-lactoglobulin) bind to BSPs and reduces BSP interactions with sperm (Menezes et al., 2016). Currently, BSPs are one of the most studied mammalian seminal plasma proteins and effects on ejaculated sperm, including capacitation, interaction with the oviduct epithelium and fertilization. That BSPs interact with components of semen extenders suggest that these proteins are potential targets for development of biomolecules that could enhance assisted reproductive technologies.

Seminal plasma phospholipase A2 (PLA2) participates in capacitation, acrosome reaction and sperm-oocyte membrane fusion (Soubeyrand et al., 1997; Pietrobon et al., 2005; Roldan and Shi, 2007), promotes release of fatty acids and phospholipids involved in final stages of gamete fusion (Roldan, 1998) and has antimicrobial effects. Furthermore, its expression in bovine seminal plasma is associated with fertility (Moura et al., 2006). Osteopontin (OPN) concentrations in bovine seminal plasma were related to in vivo fertility of Holstein bulls (Killian et al., 1993; Moura et al., 2006) and to fertilizing capacity of cauda epididymal sperm treated with accessory sex gland fluid in IVF trials (Henault et al., 1995; Moura et al., 2007b). OPN is mainly secreted by the accessory sex glands and binds to sperm after ejaculation and after they contact secretions of the oviduct and are capacitated (Souza et al., 2008). Also, OPN has a calcium binding site and a domain to link with heparin, consistent with its effects on sperm capacitation (Monaco et al., 2009; Boccia et al., 2013).

Alterations in the OPN gene reduce seminal plasma OPN concentration (Rorie et al, 2016). Furthermore, in IVF studies, percentage of fertilized bovine oocytes was significantly reduced by addition of OPN antibodies to fertilization media and exposure of sperm or oocytes to antibodies against alpha $\mathrm{V}$ and alpha5 integrins before fertilization (Gonçalves et al., 2007). Also, pre-treatment of bovine sperm and oocytes with OPN enhances both in vitro fertilization and early embryo development (Gonçalves et al., 2008a, b). The 
RGD amino acid sequence of osteopontin mediates its link with $\alpha 5$ and $\alpha$ v integrins (Denhardt, 2002; Wai and Kuo, 2004) and the ability of osteopontin to support cell adhesion is prevented when the RGD sequence is mutated (Liaw et al., 1995; Xuan et al., 1995). Treatment of sperm or oocytes with an RGD peptide, but not with an RGE sequence, reduced both the number of sperm bound to the zona pellucida and fertilization rates, similar to effects of anti-osteopontin antibodies. It appears that OPN interacts with sperm through integrins (Gonçalves et al., 2007). Incubation of oocytes with osteopontin purified from bovine milk increased cleavage rates on day 4 , blastocyst development on day 8 and hatched blastocysts on day 11 (Gonçalves et al., 2007). Furthermore, OPN purified from milk improved sperm capacitation and addition of OPN to IVF media enhanced bovine blastocyst formation (Monaco et al., 2009). Moreover, in an IVF system, using frozenthawed bull semen, OPN improved fertilization rates and blastocyst development on day 8 (Gonçalves et al., 2008a). In swine, supplementation of fertilization media with recombinant rat OPN enhanced fertilization rates by $41 \%$ and reduced polyspermy (Hao et al., 2006). Exogenous OPN added to IVF media improved cleavage rates and swine embryo development, and inhibited apoptosis and DNA fragmentation (Hao et al., 2008). Moreover, anti-OPN antibodies decreased rates of in vitro fertilization and blastocyst growth in mice (Liu et al., 2015). Clearly, OPN affects fertilization and post-fertilization events.

Osteopontin is typically involved in cell adhesion, tissue and extracellular remodeling, inflammation and immune-mediated events (Denhardt, 2002; Wai and Kuo, 2004; Rittling and Singh, 2015; Bouleftour et al., 2016). Despite substantial knowledge regarding actions of osteopontin in several tissues, an understanding of its function in male reproduction is far from complete. There is general consensus that OPN secreted by the accessory sex glands binds to sperm during ejaculation through integrins and that the integrin-OPN complex interacts with the zona pellucida (D'Cruz, 1996). This model is supported by the presence of OPN in bovine oviductal fluid (Gabler et al., 2003). Additionally, OPN binds to the CD44 receptor, which usually participates in cell adhesion (Cichy and Puré, 2003), and has been expressed in sperm (Bains et al., 2002) and oocyte membranes (Schoenfelder and Einspanier, 2003). In the bull, OPN binds to the acrosome at ejaculation (Cancel et al., 1999) and this sperm-OPN link is preserved after sperm contacts with oviductal fluid and undergoes an acrosome reaction in vitro (Souza et al., 2008). In addition to sperm binding, OPN interacts with the zona pellucida and oolemma of bovine oocytes (Souza et al., 2008). Consequently, we propose that OPN adheres to sperm and this complex connects to the zona pellucida or to OPN-zona pellucida, as OPN can form high-affinity bonds with other OPN molecules (Kaartinen et al., 1999;
Goldsmith et al., 2002). When entering the periviteline space, OPN attached to the post-equatorial segment would mediate the interaction of sperm and oolema, also through integrins and/or CD44. Integrins ( $\alpha \mathrm{v}$ and a5) are present in bovine (Erikson et al., 2008) and human sperm (Fusi et al., 1996; Reddy et al., 2003), as well as on human oolema (D'Cruz, 1996) and CD44 transmembrane glycoproteins are present in bovine sperm and oocytes. Interactions of sperm OPN with oocyte integrins and $\mathrm{CD} 44$ receptors could trigger intracellular signaling, as reported for other cell types (Wai and Kuo, 2004; Rangaswami et al., 2006), and affect fertilization and early embryo development.

\section{Metabolomics}

Metabolites are the result of metabolic reactions associated with various biochemical pathways (Dunn et al. 2011). Many of these molecules have important roles in biological processes and represent potential biomarkers for predicting or detecting developmental states, physiological events, diseases or specific phenotypes. Therefore, metabolomics is used to understand networks of metabolites and have provided comprehensive identification and quantification of small molecules, including amino acids, peptides, vitamins, minerals, lipids, and carbohydrates in diverse cells, tissues, fluids, organs and organisms (Oliver et al., 1998; Fiehn 2001, 2002; Dunn et al., 2005).

Substantial progress has been made in the study and development of methodological strategies for using metabolomics, metabonomics, metabolicfingerprinting, metabolite targeting, and metabolic profiling. Metabonomics is used to measure differences in levels of metabolites resulting from such factors as pathological or genetic changes, toxins, or use of drugs. Metabolic fingerprinting is a rapid method to evaluate and classify biologic samples or biopsies. Furthermore, metabolite target analysis is used to identify specific metabolic pathways of a limited number of metabolites, whereas metabolic profiling evaluates a cluster of metabolites that participate in a specific metabolic pathway (Dunn and Ellis, 2005; Hollywood et al., 2006; Holmes et al., 2008; Dunn et al., 2011; Patti et al., 2010). Metabolomics can be performed associated with other omics approaches, e.g. genomics, transcriptomics, and proteomics. For example, an Integrative Personal Omics Profile (iPOP) to identify markers for possible diseases affecting an individual could lead to an early diagnosis and perhaps prevention of certain diseases (Chen et al., 2012). Although complementary to other omics, metabolomics provides identification and quantification of products from metabolism and its pathways, analyses of modifications in metabolic reactions, and characterization of phenotypes and identification of potential biomarkers for such phenotypes (Fiehn, 2001, 2002; Dunn et al., 2005; Goodacre et al., 2004; Hollywood et al., 2006; Patti et al., 2010). 


\section{Metabolomics and reproductive biology}

Advanced and more sensitive methods are vital for addressing major questions in biology and biotechnology, including those related to assisted reproductive technologies (ART). It is well known that metabolites have critical roles in specific pathways related to fertilization, implantation and embryonic development. Some techniques used in metabolome analysis for studies of reproductive biology include proton nuclear magnetic resonance (1H NMR), mass spectrometry (MS), fourier transform infrared spectroscopy (FTIR), near infrared (NIR) and Raman (Singh and Sinclair, 2007, Seli et al., 2010a; Kovac et al., 2013; Muñoz et al., 2014a; b). Metabolomics methods have been used as noninvasive approaches to improve assessment of embryo quality (Singh and Sinclair, 2007; Bromer and Seli, 2008; Nagy et al., 2008; Seli et al., 2010a; Montag et al., 2013). For example, $1 \mathrm{H}$ NMR scans compared metabolomes in the culture media for human embryos before transfer. In that study, glutamate was associated with subsequent developmental potential (Seli et al., 2008). In addition, NIR, Raman and 1H NMR used for metabolome analysis of human embryo culture media were valuable for predicting successful implantation and pregnancy after IVF (Seli et al., 2007, 2008, 2010b). FTIR metabolomics were used to determine gender of bovine embryos (Muñoz et al., 2014a, b). This is also an effective and non-invasive method to determine embryo viability and the metabolic profile of blood plasma from recipient cows. Further, FTIR can be used to identify superior embryos and recipient females for optimum pregnancy outcome (Muñoz et al., 2014b).

As indicated above, methods of conventional semen evaluation most often give only descriptive information and have limitations to predict in fertility. However, various molecular approaches, such as metabolomics, have provided more in depth understanding of mechanisms causing male infertility (Deepinder et al. 2007; Aitken, 2010). Metabolomics has promise in identifying potential biomarkers of male fertility and infertility (Gilany et al., 2014; Goodacre et al., 2004; Deepinder et al., 2007; Kovac et al., 2013). The presence or changes in specific metabolites could be related to male gamete functions, perhaps enabling evidence-based techniques to prevent or mitigate infertility (Aitken, 2010). Metabolomics approach using Raman spectroscopy to analyze human seminal plasma facilitated diagnosis of normospermic and asthenozoospermic men (Gilany et al., 2014). Furthermore, 1H NMR identified fertility-associated biomarkers in seminal plasma and serum of high- and low-fertility bulls. Metabolites, such as citrate, tryptamine, taurine, and leucine were identified in seminal plasma, whereas asparagine, glycogen, citrulline, and isoleucine were present in serum (Kumar et al., 2015). Using 1HNMR, Hamamah et al. (1998) detected increased choline/citrate, choline/lactate, and glycerophosphorylcholine/choline ratios in seminal plasma of men afflicted with spermatogenic failure versus those with obstructive azoospermia. Several small molecular markers were identified in the urine of men with normozoospermic infertility using liquid chromatography-mass spectrometry (LC-MS) in combination with bioinformatics and multivariate analyses. In this research, leukotriene E4,3hydroxypalmitoylcarnitine, aspartate, xanthosine, and methoxytryptophan were biomarkers of infertility (Zhang et al., 2014). Clearly, metabolomics can be used to identify molecular markers of male fertility.

\section{Conclusions}

In recent decades, methods in proteomics and metabolomics have enabled detection of unprecedented numbers of molecules in the seminal plasma of farm animals, wild species and humans. This broadens our knowledge regarding roles of these molecules and their contributions to male fertility. Metabolomics can identify numerous classes of substances associated with metabolic pathways, leading to challenges in interpretation. Empirical associations exist between specific seminal proteins (Table 1), metabolites and fertility indexes. Experiments also confirm cause and effect relations between seminal plasma proteins (e.g.osteopontin and BSPs) and IVF and early embryo development, suggesting that seminal proteins have potential in animal biotechnology.

Studies to describe components of the seminal plasma are vital to construct comprehensive libraries of seminal plasma compounds. As many as 4,000 proteins have already been identified in human seminal plasma, although there may be up to 10,000 present (Gilany et al., 2014). A human proteome atlas (https://www.proteinatlas.org/) of human tissues and organs is under development (Omenn et al., 2017; Uhlén et al., 2015; Thul et al., 2017). Fundamental research sets the foundation of science and technology. However, investigations that use omics approaches and reproduction need to be focused on finding markers of traits that are important for livestock industry in different regions of the world. Lessons could be learned from translational research, where research is carried out by multidisciplinary teams, joining efforts from basic science, applied investigators and professionals in the front of technology. 
Table 1. Functional groups and mechanism of actions of major seminal plasma proteins.

\begin{tabular}{|c|c|c|c|}
\hline $\begin{array}{l}\text { Major } \\
\text { functional } \\
\text { group }\end{array}$ & Protein & Mechanism of action & Major references \\
\hline \multirow{5}{*}{$\begin{array}{l}\text { Proteins } \\
\text { involved in } \\
\text { sperm } \\
\text { protection }\end{array}$} & $\begin{array}{l}\text { Glutathione } \\
\text { peroxidase }\end{array}$ & $\begin{array}{l}\text { Catalyzes reduction of } \mathrm{H}_{2} \mathrm{O}_{2} \text {, protects } \\
\text { sperm against excessive ROS. }\end{array}$ & $\begin{array}{l}\text { (Halliwell and Gutteridge, 1990; } \\
\text { rams); (Perry et al., 1992; } \\
\text { Dacheux et al., 2005; bulls) }\end{array}$ \\
\hline & $\begin{array}{l}\text { Acidic seminal } \\
\text { fluid protein }\end{array}$ & $\begin{array}{l}\text { Sperm decapacitation, oxidative } \\
\text { stress control, survival of } \\
\text { cryopreserved sperm }\end{array}$ & $\begin{array}{l}\text { (Einspanier et al., 1993; } \\
\text { Schöneck et al., 1996; bull); } \\
\text { (Dostàlovà et al., 1994; bull); } \\
\text { (Jobim et al., 2004; bull) }\end{array}$ \\
\hline & Lactoferrin & $\begin{array}{l}\text { Ion chelators, protects sperm against } \\
\text { effects of lipid peroxidation }\end{array}$ & (Ochsendorf, 1999; men) \\
\hline & Albumin & $\begin{array}{l}\text { Binds to lipid peroxides in sperm } \\
\text { membrane, sperm protection }\end{array}$ & $\begin{array}{l}\text { (Alvarez and Storey, 1983; } \\
\text { rabbit) }\end{array}$ \\
\hline & Clusterin & $\begin{array}{l}\text { Chaperone and sperm membrane } \\
\text { remodeling, protects against female } \\
\text { reproductive tract immune response, } \\
\text { binds to damage sperm membrane }\end{array}$ & $\begin{array}{l}\text { (Humphreys et al., 1999; men); } \\
\text { (Ibrahim et al., 1999; bull; } \\
\text { Merlotti et al., 2015; men); } \\
\text { (Bailey and Griswold, 1999; rat) }\end{array}$ \\
\hline \multirow{2}{*}{$\begin{array}{l}\text { Proteins } \\
\text { associated } \\
\text { with sperm } \\
\text { motility }\end{array}$} & Kallikrein-cinins & $\begin{array}{l}\text { Substrate for kallikrein, which } \\
\text { enhance sperm motility }\end{array}$ & (Somlev et al., 1996; bull) \\
\hline & $\begin{array}{l}\text { Angiotensin } \\
\text { converting enzyme }\end{array}$ & $\begin{array}{l}\text { Catalyzes angiotensin II formation, } \\
\text { Enhance motility. }\end{array}$ & $\begin{array}{l}\text { (Vinson et al., 1996; rat and } \\
\text { men; Costa and Thundathil, } \\
\text { 2012; bull) }\end{array}$ \\
\hline \multirow{3}{*}{$\begin{array}{l}\text { Proteins } \\
\text { involved in } \\
\text { sperm } \\
\text { capacitation, } \\
\text { acrosome } \\
\text { reaction and } \\
\text { fertilization }\end{array}$} & $\begin{array}{l}\text { Binder of sperm } \\
\text { proteins }\end{array}$ & $\begin{array}{l}\text { Bind to sperm at ejaculation; mediate } \\
\text { gametes interaction, phospholipids } \\
\text { and cholesterol efflux from sperm } \\
\text { membrane; enhance in vitro } \\
\text { fertilization and } \\
\text { development. }\end{array}$ & $\begin{array}{l}\text { (Manjunath and Thérien, 2002; } \\
\text { bull); (Gwathmey et al., 2006; } \\
\text { bull); (Thérien et al., 1999; bull) } \\
\text { (Rodriguez-Villamil et al., 2016; } \\
\text { bull); Manjunath et al., 2002; } \\
\text { bull; Plante et al., 2016; bull) }\end{array}$ \\
\hline & Phospholipase A2 & $\begin{array}{l}\text { Release of fatty acids and } \\
\text { phospholipids involved in final } \\
\text { stages of gamete fusion; } \\
\text { antimicrobial effects. }\end{array}$ & $\begin{array}{l}\text { (Soubeyrand et al., 1997; bull; } \\
\text { Pietrobon et al., 2005; mouse; } \\
\text { Roldan and Shi, 2007); Moura et } \\
\text { al., 2006; bull) }\end{array}$ \\
\hline & Osteopontin & $\begin{array}{l}\text { Binds to sperm acrosome after } \\
\text { ejaculation; sperm capacitation; } \\
\text { interacts with sperm through } \\
\text { integrins, interacts with zona } \\
\text { pellucida and oolemma; binds to } \\
\text { sperm CD44 receptor; enhances in } \\
\text { vitro fertilization and embryo } \\
\text { development; reduces polyspermy } \\
\text { and inhibits apoptosis and DNA } \\
\text { fragmentation. }\end{array}$ & $\begin{array}{l}\text { (Souza et al., 2008; bull; Cancel } \\
\text { et al., 1999; bull); (Boccia et al., } \\
\text { 2013; buffalo; Monaco et al., } \\
\text { 2009; bull); (Gonçalves et al., } \\
\text { 2007; bull; D’Cruz, 1996; men); } \\
\text { (Souza et al., 2008; bull); (Cichy } \\
\text { and Puré, 2003; men); } \\
\text { (Gonçalves et al., 2008a; bull); } \\
\text { (Hao et al., 2006; swine; Hao et } \\
\text { al., 2008; swine) }\end{array}$ \\
\hline
\end{tabular}

\section{Acknowledgments}

The present work has been supported by the Brazilian Federal Reseach Councils (CAPES and $\mathrm{CNPq}$ ) and the Ceara State Foundation for Scientific Development and Research (FUNCAP).

\section{References}

Aitken RJ, Harkiss D, Buckingham D. 1993 Relationship between iron catalysed lipid peroxidation potential and human sperm function. $J$ Reprod Fertil, 98:257-265.

Aitken RJ. 2010. Whither must spermatozoa wander? The future of laboratory seminology. Asian J Androl 12:99-103.

Alvarez JG, Storey BT. 1983. Role of superoxide dismutase in protecting rabbit spermatozoa from O2 toxicity due to lipid peroxidation. Biol Reprod, 28:11291136.

Aquino-Cortez A, Pinheiro BQ, Lima DBC, Silva HVR, Mota Filho AC, Martins JAM, Rodriguez- 
Villamil P, Moura AA, Silva LDM. 2017. Proteomic characterization of canine seminal plasma. Theriogenology, 95:178-186.

Baas JW, Molan PC, Shannon P. 1983. Factors in seminal plasma of bulls that affect the viability and motility of spermatozoa. $J$ Reprod Fertil, 68:275-280.

Bailey R, Griswold MD. 1999. Clusterin in the male reproductive system: localization and possible function. Mol Cell Endocrinol, 151:17-23.

Bains R, Adeghe J, Carson J. 2002. Human sperm cells express CD44. Fertil Steril, 78:307-312.

Bergeron A, Manjunath P. 2006. New insights towards understanding the mechanisms of sperm protection by egg yolk and milk. Mol Reprod Dev, 73:1338-1344.

Boccia L, Di Francesco S, Neglia G, De Blasi M, Longobardi V, Campanil G, Gasparrini B. 2013. Osteopontin improves spermcapacitation and in vitro fertilization efficiency in buffalo (Bubalus bubalis). Theriogenology, 80:212-217.

Boe-Hansen GB, Rego JP, Crisp JM, Moura AA, Nouwens AS, Li Y, Venus B, Burns BM, McGowan MR. 2015. Seminal plasma proteins and their relationship with percentage of morphologically normal sperm in 2-year-old Brahman (Bos indicus) bulls. Anim Reprod Sci, 162:20-30.

Bouleftour W, Juignet L, Bouet G, Granito RN, Vanden-Bossche A, Laroche N, Aubin JE, LafageProust MH, Vico L, Malaval L. 2016. The role of the SIBLING, Bone Sialoprotein in skeletal biology: contribution of mouse experimental genetics. Matrix Biol. 52/54:60-77.

Bromer JG, Seli E. 2008. Assessment of embryo viability in assisted reproductive technology: shortcomings of current approaches and the emerging role of metabolomics. Curr Opin Obstet Gynecol, 20:234-241

Caballero I, Vazquez JM, Gil MA, Calvete JJ, Roca J, Sanz L, Parrilla I, Garcia EM, RodriguezMartinez H, Martinez EA. 2004. Does seminal plasma PSP-I/PSP-II spermadhesin modulate the ability of boar spermatozoato penetrate homologous oocytes in vitro? $J$ Androl, 25:1004-1012.

Caballero I, Vazquez JM, Rodriguez-Martinez H, Gill MA, Calvete JJ, Sanz L, Garcia EM, Roca J, Martinez EA. 2005. Influence of seminal plasma PSPI/PSP-II spermadhesin on pig gamete interaction. Zygote, 13:11-16.

Calero M, Rostagno A, Frangione B, Ghiso J. 2005 Clusterin and Alzheimer's disease. Subcell Biochem; 38:273-298.

Calvete JJ, Mann K, Sanz L, Raida M, TöpferPetersen E. 1996. The primary structure of BSP-30K, a major lipid-, gelatin-, and heparin-binding glycoprotein of bovine seminal plasma. FEBS Lett, 399:147-152.

Cancel AM, Chapman DA, Killian GJ. 1999. Osteopontin localization in the Holstein bull reproductive tract. Biol Reprod, 60:454-460.

Carver JA, Rekas A, Thorn DC, Wilson MR. 2003. Small heat-shock proteins and clusterin: intra- and extracellular molecular chaperones with a common mechanism of action and function? IUBMB Life,

\section{5:661-668}

Casao A, Cebrián I, Asumpção ME, Pérez-Pé R, Abecia JA, Forcada F, Cebrián-Pérez JA, MuiñoBlanco T. 2010. Seasonal variations of melatonin in ram seminal plasma are correlated to those of testosterone and antioxidant enzymes. Reprod Biol Endocrinol, 11:59-66.

Chen R, Mias GI, Li-Pook-Than J, Jiang LH, Lam HYK, Chen R, Miriami E, Karczewski KJ, Hariharan M, Dewey FE, Cheng Y, Clark M, Im H, Habegger L, Balasubramanian S, O'Huallachain M, Dudley JT, Hillenmeyer S, Haraksingh R, Sharon D, Euskirchen G, Lacroute P, Bettinger K, Boyle AP, Kasowski M, Grubert F, Seki S, Garcia M, WhirlCarrillo M, Gallardo M, Blasco MA, Greenberg PL, Snyder P, Klein TE, Altman RB, Butte AJ, Ashley EA, Gerstein M, Nadeau KC, Tang H, Snyder M. 2012. Personal omics profiling reveals dynamic molecular and medical phenotypes. Cell, 148:12931307.

Cichy J, Puré E. 2003. The liberation of CD44. J Cell Biol, 161:839-843.

Costa DS, Thundathil JC. 2012. Characterization and activity of angiotensin-converting enzyme in Holstein semen. Anim Reprod Sci, 133:35-42.

D'Cruz OJ. 1996. Adhesion molecules in human sperm-oocyte interaction: relevance to infertility. Front Biosci, 1:161-176.

Dacheux JL, Castella S, Gatti JL, Dacheux F. 2005. Epididymal cell secretory activities and the role of proteins in boar sperm maturation. Theriogenology, 63:319-341.

Dacheux JL, Belghazi M, Lanson Y, Dacheux F. 2006. Human epididymal secretome and proteome. Mol Cell Endocrinol, 250:36-42.

Deepinder F, Chowdary HT, Agarwal A. 2007. Role of metabolomic analysis of biomarkers in the management of male infertility. Expert Rev Mol Diagn, $7: 351-358$

Denhardt DT. 2002. The third international conference on osteopontin and related proteins, San Antonio, Texas, May 10-12, 2002. Calcif Tissue Int, 74:213-219.

Dogan S, Vargovic P, Oliveira R, Belser LE, Kaya A, Moura A, Sutovsky P, Parrish J, Topper E, Memili E. 2015. Sperm protamine-status correlates to the fertility of breeding bulls. Biol Reprod, 92:1-9. doi: 10.1095/biolreprod.114.124255.

Dostàlovà Z, Calvete JJ, Sanz L, Hettel C, Riedel D, Schöneck C, Einspanier R, Töpfer-Petersen E. 1994. Immunolocalization and quantitation of acidic seminal fluid protein (aSFP) in ejaculated, swim-up, and capacitated bull spermatozoa. Biol Chem Hoppe Seyler, 375:457-461.

Dunn B Ellis DI. 2005. Metabolomics: current analytical platforms and methodologies. TrAC-Trend Anal Chem, 24:285-294.

Dunn WB, Bailey NJC, Johnson HE. 2005. Measuring the metabolome: current analytical technologies. Analyst, 130:606-625.

Dunn WB, Broadhurst DI, Atherton HJ, Goodacre R, Griffin JL. 2011. Systems level studies of mammalian metabolomes: the roles of mass 
spectrometry and nuclear magnetic resonance spectroscopy. Chem Soc Rev, 40:387-426.

Einspanier R, Amselgruber W, Sinowatz F, Henle T, Ropke R, Schams D. 1993. Localization and concentrationof a new bioactive acetic seminal fluid protein (asfp) in bulls (Bos taurus). J Reprod Fertil, 98:241-244.

Elzanaty S, Erenpreiss J, Becker C. 2007. Seminal plasma albumin: origin and relation to the male reproductive parameters. Andrologia, 39:60-65.

Erikson DW, Way AL, Chapman DA, Killian GJ. 2008. Detection of osteopontin on Holstein bull spermatozoa, in cauda epididymal fluid and testis homogenates, and its potential role in bovine fertilization. Reproduction, 133:909-917.

Fiehn O. 2001. Combining genomics, metabolome analysis, and biochemical modelling to understand metabolic networks. Compar Funct Genom. 2:155-168.

Fiehn O. 2002. Metabolomics-the link between genotypes and phenotypes. Plant Mol Biol. 48:155-171.

Fink E, Schill WB, Miska W. 1989. Kinin-containing kininogen is present in human seminal plasma. Adv Exp Med Biol, 247:311-315.

Fouchécourt S, Métayer S, Locatelli A, Dacheux F, Dacheux JL. 2000. Stallion epididymal fluid proteome: qualitative and quantitative characterization; secretion and dynamic changes of major proteins. Biol Reprod, 62:1790-1803.

Fusi FM, Tamburini C, Mangili F, Montesano M, Ferrari A, Bronson R. 1996. The expression of alpha $\mathrm{v}$, alpha 5 , beta 1 and beta 3 integrin chains on ejaculated human spermatozoa varies with their functional state. Mol Hum Reprod, 2:169-175.

Gabler C, Chapman DA, Killian GJ. 2003 Expression and presence of osteopontin and integrins in the bovine oviduct during the estrous cycle. Reproduction, 126:721-729.

Gatti J, Castella S, Dacheux F, Ecroyd H, Métayer S, Thimon V, Dacheux J. 2004. Post-testicular sperm environment and fertility. Anim Reprod Sci, 82:321-339. Gilany K, Moazeni-Pourasil RS, Jafarzadeh N, Savadi-Shiraz E. 2014. Metabolomics fingerprinting of the human seminal plasma of asthenozoospermic patients. Mol Reprod Dev. 81:84-86.

Goldsmith HL, Labrosse JM, McIntosh FA, MaenpaaPH, Kaartinen MX, McKee MD. 2002. Homotypic interactions of soluble and immobilized osteopontin. Ann Biomed Eng, 30:840-850.

Gonçalves RF, Wolinetz CD, Killian GJ. 2007 Influence of arginine-glycine-aspartic acid (RGD), integrins ( $\alpha v$ and $\alpha 5)$ and osteopontin on bovine spermegg binding, and fertilization in vitro. Theriogenology, 67:468-474

Gonçalves RF, Chapman DA, Bertolla RP, Eder I, Killian GJ. 2008a. Pre-treatment of cattle semen or oocytes with purified milk osteopontin affects in vitro fertilization and embryo development. Anim Reprod Sci, 108:375-383.

Gonçalves RF, Staros AL, Killian GJ. 2008b. Oviductal fluid proteins associated with the bovine zona pellucida and the effect on in vitro sperm-egg binding, fertilization and embryo development. Reprod Domest
Anim, 43:720-729.

González-Cadavid V, Martins JA, Moreno FB, Andrade TS, Santo AC, Monteiro-Moreira AC, Moreira RA, Moura AA. 2014. Seminal plasma proteins of adult boars and correlations with sperm parameters. Theriogenology, 82:697-707.

Goodacre R, Vaidyanathan S, Dunn WB, Harrigan GG, Kell DB. 2004. Metabolomics by numbers: acquiring and understanding global metabolite data. Trends Biotechnol, 22:245-252.

Gwathmey TM, Ignotz GG, Mueller JL, Manjunath P, Suarez SS. 2006. Bovine seminal plasma proteins PDC-109, BSP-A3, and BSP-30-kDa share functional roles in storing sperm in the oviduct. Biol Reprod, 75:501-507.

Halliwell B, Gutteridge JMC. 1990. Free Radicals in Biology and Medicine. 2nd. ed. Oxford, UK: Oxford University Press.

Hao Y, Mathialagan N, Walters E, Mao J, Lai L, Becker D, Li W, Critser J, Prather RS. 2006. Osteopontin reduces polyspermy during in vitro fertilization of porcine oocytes. Biol Reprod, 75:726733.

Hao Y, Murphy CN, Spate L, Wax D, Zhong Z, Samuel M, Mathialagan N, Schatten H, Prather RS. 2008. Osteopontin improves in vitro development of porcine embryos and decreases apoptosis. Mol Reprod Dev, 75:291-298.

Hamamah S, Seguin F, Bujan L, Barthelemy C, Mieusset R, Lansac J. 1998. Quantification by magnetic resonance spectroscopy of metabolites in seminal plasma able to differentiate different forms of azoospermia. Hum Reprod. 13:132-135.

Henault MA, Killian GJ, Kavanaugh JF, Griel LC Jr. 1995. Effect of accessory sex gland fluid from bulls of differing fertilities on the ability of cauda epididymal sperm to penetrate zona-free bovine oocytes. Biol Reprod, 52:390-397.

Hinton BT, Palladino MA, Rudolph D, Labus JC. 1995. The epididymis as protector of maturing spermatozoa. Reprod Fertil Dev, 7:731-745.

Hinton BT, Palladino MA, Rudolph D, Lan ZJ, Labus JC. 1996. The role of the epididymis in the protection of spermatozoa. Curr Top Dev Biol, 33:61102.

Hohlbrugger G, Pschorr J, Dahlheim H. 1984. Angiotensin I-converting enzyme in the ejaculate of fertile and infertile men. Fertil Steril, 41:324-325.

Hollywood K, Brison DR, Goodacre R. 2006. Metabolomics: current technologies and future trends. Proteomics, 6:4716-4723.

Holmes E, Wilson ID, Nicholso JK. 2008. Metabolic phenotyping in health and disease. Cell, 134:714-717.

Humphreys DT, Carver JA, Easterbrook-Smith SB, Wilson MR. 1999. Clusterin has chaperone-like activity similar to that of small heat shock proteins. $J$ Biol Chem. 274:6875-6881.

Ibrahim NM, Troedsson MH, Foster DN, Loseth KJ, Farris JA, Blaschuk O, Crabo BG. 1999. Reproductive tract secretions and bull spermatozoa contain different clusterin isoforms that cluster cells and inhibit complement-induced cytolysis. $J$ Androl, 


\section{0:230-240.}

Ibrahim NM, Foster DN, Crabo BG. 2001a Localization of clusterin on freeze-preserved bull spermatozoa before and after glass wool-sephadex filtration. $J$ Androl, 22:891-902.

Ibrahim NM, Romano JE, Troedsson MH, Crabo BG. 2001b. Effect of scrotal insulation on clusterinpositive cells in ram semen and their relationship to semen quality. $J$ Androl, 22:863-877.

Jeulin C, Soufir JC, Weber P, Laval-Martin D, Calvayrac R. 1989. Catalase activity in human spermatozoa and seminal plasma. Gamete Res, 24:185196.

Jin YZ, Bannai S,Dacheux F, Dacheux JL, Okamura N. 1997. Direct evidence for the secretion of lactoferrin and its binding to sperm in the porcine epididymis. Mol Reprod Dev, 47:490-496.

Jobim MIM, Oberst ER, Salbego CG, Souza DO, Wald VB Tramontina F, Mattos RC. 2004. Twodimensional polyacrylamide gel electrophoresis of bovine seminal plasma proteins and their relation with semen freezability. Theriogenology, 61:255-266.

Kaartinen MT, Pirhonen A, Linnala-Kankkunen A,Mäenpää PH. 1999. Cross-linking of osteopontin bytissue transglutaminase increases its collagen binding properties. J Biol Chem, 274:1729-1735.

Kaya A, Memili E. 2016. Sperm macromolecules associated with bull fertility. Anim Reprod Sci, 169:8894.

Kikuchi M, Mizoroki S, Kubo T, Ohiwa Y, Kubota M, Yamada N, Orino K, Ohnami Y, Watanabe $\mathrm{K}$. 2003a. Seminal plasma lactoferrin but not transferrin reflects gonadal function in dogs. $J$ Vet Med Sci. 65:679-684.

Kikuchi M, Takao Y, Tokuda N, Ohnami Y, Orino K, Watanabe K. 2003b. Relationship between seminal plasma lactoferrin and gonadal function in horses. $J$ Vet Med Sci, 65:1273-1274.

Killian GJ, Chapman DA, Rogowski LA. 1993. Fertility-associated proteins in Holstein bull seminal plasma. Biol Reprod, 49:1202-1207.

Kovac JR, Pastuszak AW, Lamb DJ. 2013. The use of genomics, proteomics, and metabolomics in identifying biomarkers of male infertility. Fertil Steril, 99:998-1007.

Kraus M, Tichá M, Zelezná B. 2005. Characterization of human seminal plasma proteins homologous to boar AQN spermadhesins. J Reprod Immunol, 65:33-46.

Kumar A, Kroetsch T, Blondin P, Anzar M. 2015 Fertility-associated metabolites in bull seminal plasma and blood serum: (1) H nuclear magnetic resonance analysis. Mol Reprod Dev, 82:123-131.

Liaw L, Lindner V, Schwartz SM, Chambers AF, Giachelli CM. 1995. Osteopontin and beta 3 integrin are coordinately expressed in regenerating endothelium in vivo and stimulate Arg-Gly-Asp-dependent endothelial migration in vitro. Circ Res, 77:665-672.

Liu Q, Xie QZ, Zhou Y, Yang J. 2015. Osteopontin is expressed in the oviduct and promotes fertilization and preimplantation embryo development of mouse. Zygote, 23:622-630.

MacLeod J. 1943. The role of oxygen in the metabolism and motility of the human spermatozoa. $\mathrm{Am}$ J Physiol, 138:512-518.

Manjunath P, Sairam MR. 1987. Purification and biochemical characterization of three major acidic proteins (BSP-A1, BSP-A2 and BSP-A3) from bovine seminal plasma. Biochem $J, 241(3): 685-692$.

Manjunath $P$, Nauc $V$, Bergeron $A$, Menard $M$. 2002. Major proteins of bovine seminal plasma bind to the low-density lipoprotein fraction of hen's egg yolk. Biol Reprod, 67:1250-1258.

Manjunath P, Therien I. 2002. Role of seminal plasma phospholipid-binding proteins in sperm membrane lipid modification that occurs during capacitation. $J$ Reprod Immunol, 53:109-119.

Manjunath P, Lefebvre J, Jois PS, Fan J, Wright MW. 2009. New nomenclature for mammalian BSP genes. Biol Reprod, 80:394-397.

Matsushita K, Miyake $\mathbf{H}$, Chiba $K$, Fujisawa $M$. 2016. Clusterin produced by Sertoli cells inhibits heat stress induced apoptosis in the rat testis. Andrologia, 48:11-19.

Menezes BM, van Tilburg M, Plante G, De Oliveira RV, Moura AA, Manjunath P. 2016. Milk proteins interact with goat Binder of SPerm (BSP)proteins and decrease their binding to sperm. Cell Tissue Res, 366:427-442.

Menezes EB, De Oliveira RV, Van Tilburg MF, Babosa EA, Nascimento NV, Velho ALMCS, Moren FB, Moreira RA, Monteiro-Moreira ACO, Carvalho GMC, Ramos AF, Memili E, Moura AA. 2017. Proteomic analysis of seminal plasma from locallyadapted Curraleiro Pé-Duro bulls (Bos taurus): identifying biomarkers involved in sperm physiology in endangered animals for conservation of biodiversity. Anim Reprod Sci. 183:86-101.

Meri S, Jarva H. 2001. Complement regulatory proteins. In: Encyclopedia of Life Sciences (eLS). London: Nature Publ. pp. 1-7.

Merlotti A, Dantas E, Remes Lenicov F, Ceballos A, Jancic C, Varese A, Rubione J, Stover S, Geffner J, Sabatte J. 2015. Fucosylated clusterin in semen promotes the uptake of stress-damaged proteins by dendritic cells via DC-SIGN. Hum Reprod, 30:15451556.

Métayer S, Dacheux F, Guérin Y, Dacheux JL, Gatti JL. 2001. Physiological and enzymatic properties of the ram epididymal soluble form of germinal angiotensin Iconverting enzyme. Biol Reprod, 65:1332-1339.

Monaco E, Gasparrini B, Boccia L, De Rosa A, Attanasio L, Zicarelli L, Killian G. 2009. Effect of osteopontin (OPN) on in vitro embryo development in cattle. Theriogenology, 71:450-457.

Montag M, Toth B, Strowitzki T. 2013. New approaches to embryo selection. Reprod Biomed Online. 27:539-546.

Moura AA. 2005. Seminal plasma proteins and fertility indexes in the bull: the case for osteopontin. Anim Reprod, 2:3-10.

Moura AA, Koc H, Chapman DA, Killian GJ. 2006. Identification of accessory sex gland fluid proteins as related to fertility indexes of dairy bulls: a proteomic approach. J Androl, 27:201-211. 
Moura AA, Chapman DA, Koc H, Killian GJ. 2007a. A comprehensive proteomic analysis of the accessory sex gland fluid from mature Holstein bulls. Anim Reprod Sci, 98:169-188.

Moura AA, Chapman DA, Killian GJ. 2007b. Proteins of the accessory sex glands associated with the oocyte-penetrating capacity of cauda epididimal sperm from Holstein bulls of documented fertility. Mol Reprod Dev, 74:214-222.

Moura AA, Souza CE, Stanley BA, Chapman DA, Killian GJ. 2010. Proteomics of cauda epididymal fluid from mature Holstein bulls. J Proteomics, 73:20062020.

Muñoz M, Uyar A, Correia A, Diez, FernandezGonzalez A, Caamano JN, Trigal B, Carrocera S, Seli E, Gomez E. 2014a. Non-invasive assessment of embryonic sex in cattle by metabolic fingerprinting of in vitro culture medium. Metabolomics, 10:443-451.

Muñoz M, Uyar A, Correia E, Ponsart C, GuyaderJoly C, Martinez-Bello D, Marquant-Le Guienne B, Fernandez-Gonzalez A, Diez C, Caamano JN, Trigal B, Humblot P, Carrocera S, Martin D, Seli E, Gomez E. 2014b. Metabolomic prediction of pregnancy viability in superovulated cattle embryos and recipients with fourier transform infrared spectroscopy. Biomed Res Int. 2014:608579.

Nagy Z, Sakkas, D, Behr B. 2008. Symposium: innovative techniques in human embryo viability assessment. Non-invasive assessment of embryo viability by metabolomic profiling of culture media ('metabolomics'). Reprod Biomed Online 17:502-507.

Nozaki A, Ikeda M, Naganuma A, Nakamura T, Inudoh M, Tanaka K, Kato N. 2003. Identification of a lactoferrin-derived peptide possessing binding activity to hepatitis C virus E2 envelope protein. $J$ Biol Chem, 278:10162-10173.

Ochsendorf FR. 1999. Infections in the male genital tract and reactive oxygen species. Hum Reprod Update, 5:399-420.

Ohta A, Mohri T, Ohyashiki T. 1989. Effect of lipid peroxidation on membrane-bound $\mathrm{Ca} 2$-ATPase activity of the intestinal brush-border membrane. Biochim Biophys Acta, 984:151-157.

Oliveira RV, Dogan S, Belser LE, Kaya A, Topper E, Moura A, Thibaudeau G, Memili E. 2013. Molecular morphology and function of bull spermatozoa linked to histones and associated with fertility. Reproduction, 146:263-272.

Oliver SG, Winson MK, Kell DB, Baganz F. 1998. Systematic functional analysis of the yeast genome. Trends Biotechnol, 16:373-378.

Omenn GS, Lane L, Lundberg EK., Overall CM, Deutsch EW. 2017. Progress on the HUPO draft human proteome: 2017 metrics of the human proteome project. $J$ Proteome Res. 16:4281-4287.

Patti GJ, Shriver LP, Wassif CA, Woo HK, Uritboonthai W, Apon J, Manchester M, Porter FD, Siuzdak G. 2010. Nanostructure-initiator mass spectrometry (NIMS) imaging of brain cholesterol metabolites in Smith-Lemli-Opitz syndrome. Neuroscience, 170:858-864.

Perry AC, Jones R, Niang LS, Jackson RM, Hall L.
1992. Genetic evidence for an androgen-regulated epididymal secretory glutathione peroxidase whose transcript does not contain a selenocysteine codon. Biochem J, 285:863-870.

Pietrobon EO, Soria M, Domínguez LA, MonclusMde L, Fornés MW. 2005. Simultaneous activation of PLA2 and PLC are required to promote acrosomal reaction stimulated by progesterone via Gproteins. Mol Reprod Dev, 70:58-63.

Plante G, Thérien I, Lachance C, Leclerc P, Fan J, Manjunath P. 2014. Implication of the human Binder of SPerm Homolog 1 (BSPH1) protein in capacitation. Mol Hum Reprod, 20:409-421

Plante G, Lusignan MF, Lafleur M, Manjunath P. 2015. Interaction of milk proteins and Binder of Sperm (BSP) proteins from boar, stallion and ram semen. Reprod Biol Endocrinol, 13:92-112.

Plante G, Manjunath P. 2015. Murine binder of sperm protein homolog 1: a new player in HDL-induced capacitation. Reproduction, 149:367-376.

Plante G, Prud'homme B, Fan J, Lafleur $M$, Manjunath P. 2016. Evolution and function of mammalian binder of sperm proteins. Cell Tissue Res, 363:105-127.

Pucci S, Bonanno E, Pichiorri F, Angeloni C, Spagnoli LG. 2004. Modulation of different clusterin isoforms in human colon tumorigenesis. Oncogene, 23:2298-2304

Rangaswami H, Bulbule A, Kundu GC. 2006. Osteopontin: role in cell signaling and cancer progression. Trends Cell Biol, 16:79-87.

Reddy VRK, Rajeev S, Gupta V. 2003. $\alpha 6 \beta 1$ integrin is a potential clinical marker for evaluating sperm quality in men. Fertil Steril, 79:1590-1596.

Rego JP, Moura AA, Nouwens AS, McGowan MR, Boe-Hansen GB. 2014. Seminal plasma proteome of electroejaculated Bos indicus bulls. Anim Reprod Sci, 148:1-17

Rego JPA, Martins JM, Wolf CA, Van Tilburg M, Moreno F, Monteiro-Moreira AC, Moreira RA, Santos DO, Moura AA. 2016. Proteomic analysis of seminal plasma and sperm cells and their associations with semen freezability in Guzerat bulls. J Anim Sci, 94:5308-5320

Rittling S R, Singh R. 2015. Osteopontin in immunemediated diseases. J Dent Res, 94:1638-1645.

Rodríguez-Villamil P, Hoyos-Marulanda V, Martins JA, Oliveira AN, Aguiar LH, Moreno FB, Velho AL, Monteiro-Moreira AC, Moreira RA, Vasconcelos IM, Bertolini M, Moura AA. 2016. Purification of binder of sperm protein 1 (BSP1) and its effects on bovine in vitro embryo development after fertilization with ejaculated and epididymal sperm. Theriogenology, 85:540-554.

Roldan ER.1998. Role of phospholipases during sperm acrosomalexocytosis. Front Biosci, 3:D1109-D1119.

Roldan ER, Shi QX. 2007. Sperm phospholipases and acrosomal exocytosis. Front Biosci, 2:89-104.

Romão MJ, Kolln I, Dias JM, Carvalho AM, Romero A, Varela PF, Sanz L, Topfer-Petersen E, CalveteJJ. 1997. Crystal structure of acidic seminal fluid protein (asfp) at 1.9 A resolution: a bovine 
polypeptide of the spermadhesin family. $J$ Mol Biol, 274:650-660.

Rorie RW, Williams CL, Lester TD. 2016 Association of osteopontin gene promoter single nucleotide polymorphisms with bull semen quality. $A d v$ Reprod Sci, 4:1-7.

Salehi M, Akbari H, Heidari MH, Molouki A, Murulitharan K, Moeini H, Novin MG, Aabed F, Taheri H, Fadaei F, Mohsenzadeh M, Jafari M, Pirouzi A, Heidari R. 2013. Correlation between human clusterin in seminal plasma with sperm protamine deficiency and DNA fragmentation. Mol Reprod Dev, 80:718-724.

Santos EA, Sousa PC, Martins JA, Moreira RA, Monteiro-Moreira AC, Moreno FB, Oliveira MF, Moura AA, Silva AR. 2014. Protein profile of the seminal plasma of collared peccaries (Pecari tajacu Linnaeus, 1758). Reproduction, 147:753-764.

Schill WB. 1989. Significance of the kallikrein-kinin system in andrology. In: Fritz H, Schimidt I, Dietze G (Ed.). Thekallikrein-kinin System in Health and Disease. Braunschweig: Limbach Verlag. pp. 171-203.

Schoenfelder M, Einspanier R. 2003. Expression of hyaluronan synthases and corresponding hyaluronan receptors is differentially regulated during oocyte maturation in cattle. Biol Reprod, 69:269-277.

Schöneck C, Braun J, Einspanier R. 1996. Sperm viability is influenced in vitro by the bovine seminal protein aSFP: effects on motility, mitochondrial activity and lipid peroxidation. Theriogenology, 45:633-642.

Seli E, Sakkas D, Scott R, Kwok SC, Rosendahl SM, Burns, DH. 2007. Noninvasive metabolomic profiling of embryo culture media using Raman and near-infrared spectroscopy correlates with reproductive potential of embryos in women undergoing in vitro fertilization. Fertil Steril, 88:1350-1357.

Seli E, Botros L, Sakkas D, Burns DH. 2008 . Noninvasive metabolomic profiling of embryo culture media using proton nuclear magnetic resonance correlates with reproductive potential of embryos in women undergoing in vitro fertilization. Fertil Steril, 90:2183-2189.

Seli E, Robert C, Sirard MA. 2010a. OMICS in assisted reproduction: possibilities and pitfalls. $\mathrm{Mol}$ Hum Reprod, 16:513-530.

Seli E, Vergouw CG, Morita H, Botros L, Roos P, Lambalk CB, Yamashita N, Kato O, Sakkas D. 2010b. Noninvasive metabolomic profiling as an adjunct to morphology for noninvasive embryo assessment in women undergoing single embryo transfer. Fertil Steril. 94:535-542.

Silva HVR, Rodríguez-Villamil P, Magalhaes FF, Nunes TGP, Freitas LA, Ribeiro LR, Silva AR, Moura AA, Silva LDM. 2018. Seminal plasma and sperm proteome of ring-tailed coatis (Nasua nasua, Linnaeus, 1766). Theriogenology, 111:34-42.

Singh R, Sinclair KD. 2007. Metabolomics: approaches to assessing oocyte and embryo quality. Theriogenology, 68:S56-62.

Somlev B, Helili K, Karcheva V. 1996. Tissue kallikrein activity in seminal plasma of bovine ejaculates with different quality. Theriogenology,

\section{5:471-475.}

Soubeyrand S, Khadir A, Brindle Y, Manjunath P. 1997. Purification of a novel phospholipase A2 from bovine seminal plasma. J Biol Chem, 272:222-227.

Souza CEA, Moura AA, Monaco E, Killian GJ. 2008. Binding patterns of bovine seminal plasma proteins $\mathrm{A} 1 / \mathrm{A} 2,30 \mathrm{kDa}$ and osteopontin on ejaculated sperm before and after incubation with isthmic and ampullaryoviductal fluid. Anim Reprod Sci, 105:72-89.

Souza CEA, Rego JP, Lobo CH, Oliveira JT, Nogueira FC, Domont GB, Fioramonte M, Gozzo FC, Moreno FB, Monteiro-Moreira AC, Figueiredo JR, Moura AA. 2012. Proteomic analysis of the reproductive tract fluids from tropically-adapted Santa Ines rams. J Proteomics, 75:4436-4456.

Suarez SS. 2016. Mammalian sperm interactions with the female reproductive tract. Cell Tissue Res, 363:185194.

Tenniswood MP, Guenette RS, Lakins J, Mooibroek M, Wong P, Welsh JE. 1992. Active cell death in hormone-dependent tissues. Cancer Metastasis Rev, 11:197-220.

Thaler CJ, Vanderpuye OA, McIntyre JA, Faulk WP. 1990. Lactoferrin binding molecules in human seminal plasma. Biol Reprod, 43:712-717.

Thérien I, Bleau G, Manjunath P. 1995. Phosphatidylcholine-binding proteins of bovine seminal plasma modulate capacitation of spermatozoa by heparin. Biol Reprod, 52:1372-1379.

Thérien I, Moreau R, Manjunath P. 1998. Major proteins of bovine seminal plasma and high-density lipoprotein induce cholesterol efflux from epididymal sperm. Biol Reprod, 59:768-776.

Thérien I, Moreau R, Manjunath P. 1999. Bovine seminal plasma phopholipid binding proteins stimulate phospholipid efflux from epididymal sperm. Biol Reprod, 61:590-598.

Thul PJ, Åkesson L, Wiking M, Mahdessian D, Geladaki A, Ait Blal H, Alm T, Asplund A, Björk L, Breckels LM, Bäckström A, Danielsson F, Fagerberg L, Fall J, Gatto L, Gnann C, Hober S, Hjelmare M, Johansson F, Lee S, Lindskog C, Mulder J, Mulvey CM, Nilsson P, Oksvold P, Rockberg J, Schutten R, Schwenk JM, Sivertsson Å, Sjöstedt E, Skogs M, Stadler C, Sullivan DP, Tegel H, Winsnes C, Zhang C, Zwahlen M, Mardinoglu A, Pontén F, von Feilitzen K, Lilley KS, Uhlén M, Lundberg E. 2017. A subcellular map of the human proteome. Science, 356:6340.

Trougakos IP, Poulakou M, Stathatos M, Chalikia A, Melidonis A, Gonos ES. 2002. Serum levels of the senescence biomarker clusterin/apolipoprotein J increase significantly in diabetes type II and during development of coronary heart disease or at myocardial infarction. Exp Gerontol, 37:1175-1187.

Uhlén M, Fagerberg L, Hallstrm BM, Lindskog C, Oksvold P, Mardinoglu A, Sivertsson Å, Kampf C, Sjöstedt E, Asplund A, Olsson I, Lundberg E, Navani S, Szigyarto CA, Odeberg J, Djureinovic D, Takanen JO, Hober S, Alm T, Edqvist PH, Berling H, Tegel H, Mulder J, Rockberg J, Nilsson P, Schwenk JM, Hamsten M, von Feilitzen K, Forsberg 
M, Persson L, Johansson F, Zwahlen M, von Heijne G, Nielsen J, Pontén F. 2015. Proteomics. Tissuebased map of the human proteome. Science. 347:1260419.

van Tilburg MF, Salles MG, Silva MM, Moreira RA, Moreno FB, Monteiro-Moreira AC, Martins JA, Cândido MJ, Araújo AA, Moura AA. 2014. Semen variables and sperm membrane protein profile of Saanen bucks (Capra hircus) in dry and rainy seasons of the Northeastern Brazil (3 degrees S). Int $J$ Biometeorol, 59:561-573.

Vinson GP, Mehta J, Evans S, Matthews, S, Puddefoot, JR, Saridogan E, Holt WV, Djahanbakhch O. 1996. Angiotensin II stimulates sperm motility. Regul Pept, 67:131-135.

Wai PY, Kuo PC. 2004. The role of osteopontin in tumor metastasis. J Surg Res, 121:228-241.

Wehrli P, Charnay Y, Vallet P, Zhu G, Harmony J, Aronow B, Tschopp J, Bouras C, Viard-Leveugle I, French LE, Giannakopoulos P. 2001. Inhibition of postischemic brain injury by clusterin overexpression. Nat Med, 7:977-979.

Xuan JW, Hota C, Shigeyama Y, D'Errico JA, Somerman MJ, Chambers AF. 1995. Site-directed mutagenesis of the arginine-glycine-aspartic acid sequence in osteopontin destroys cell adhesion and migration functions. JCell Biochem, 57:680-690.

Zhang J, Mu X, Xia Y, Martin FL, Hang W, Liu L, Tian M, Huang Q, Shen H. 2014. Metabolomic analysis reveals a unique urinary pattern in normozoospermic infertile men. $J$ Proteome Res. 13:3088-3099. 